\title{
Three Perspectives on Information Literacy in Academia: Talking to Librarians, Faculty, and Students
}

\author{
Anna Yevelson-Shorsher and Jenny Bronstein
}

This study presents three perspectives on the subject of information literacy skills in academia by examining the perceptions of students, teaching faculty, and librarians. Information literacy (sometimes referred to as critical thinking or research skills) has become a crucial set of skills in academic work since developments in informational and technological environments have given students access to vast amounts of information that is often unsupported, unfiltered, and unreliable. Data collected from 32 semistructured interviews were analyzed using thematic analysis. Findings show that students felt they lacked adequate information literacy skills, did not receive sufficient help from the faculty, and were unaware of the resources and services the library offered. Professors, however, considered such skills important and expected students to obtain them during their studies. The library staff were aware of students' difficulties in acquiring these skills and have made efforts to develop programs to remedy the situation. However, these programs were not always successful due to a lack of awareness by students, and the incompatibility of such programs with their needs and the expectations of their instructors. By contrasting the views, needs, and expectations of the three populations studied, findings from the study show that greater collaboration and communication among faculty, librarians, and students is needed to improve students' information literacy skills. The study also provides the LIS field with an outline of an "ideal" information literacy training for students as it is reflected in the combined views of the participated populations.

\section{Introduction}

The information age and its far-reaching technological developments have changed the ways in which users relate to and use information, ${ }^{1}$ making information literacy skills an essential set of skills and competencies that impact the daily lives of individuals living in an information society. The term "information literacy" was first used by

\footnotetext{
*Anna Yevelson-Shorsher is Head Librarian in charge of the Humanities Collection at Aranne Library at Ben Gurion University of the Negev; e-mail: annay@bgu.ac.il. Jenny Bronstein is Senior Lecturer in the Department of Information Science at Bar-Ilan University; email: jenny.bronstein@biu.ac.il. (02018 Anna Yevelson-Shorsher and Jenny Bronstein, Attribution-NonCommercial (http://creativecommons.org/ licenses/by-nc/4.0/) CC BY-NC.
} 
Zurkowski, ${ }^{2}$ who suggested that informationally literate people know how to apply information resources to their work. In recent years, the American Library Association has defined information literacy (IL) as a set of abilities requiring individuals to "recognize when information is needed and have the ability to locate, evaluate, and use effectively the needed information." ${ }^{3}$ Other studies have described information literacy as a socially situated practice that is a catalyst for learning, ${ }^{4}$ necessary for individuals to become socially and civically involved in their communities ${ }^{5}$ and crucial for success in the working world where people are accustomed to rapid technological change. ${ }^{6}$

These skills are especially important in academic environments; since the advent of the Internet, students have lacked the necessary information literacy background-yet they have become more dependent on the information they find online for their research needs. Although they have enough technological knowledge to manage different devices, they do not always know how to search, retrieve, and evaluate information efficiently from all the sources available to them ${ }^{7}$ and sometimes lack critical thinking skills. ${ }^{8}$ They are knowledgeable in the technical aspects of Internet surfing, but they are often unable to distinguish technical abilities from information literacy skills. ${ }^{9}$ Also, they are unfamiliar with the services provided by libraries or the support and guidance provided by librarians, perceiving them as responsible only for organizing the shelves. ${ }^{10}$

Social media environments developed within the last decade have also challenged traditional definitions of information literacy. Prior studies define information literacy as a metaliteracy that "enables the acquisition of new skills and knowledge"11 and incorporates multiple literacies (such as digital literacy, media literacy, visual literacy, and information technology fluency). ${ }^{12}$ As a result of these rapid technological developments, the Association of College and Research Libraries (ACRL) adopted a new Framework for Information Literacy for Higher Education, ${ }^{13}$ which proposes six conceptual understandings that frame a series of interrelated ideas about information, research, and scholarship and are termed threshold concepts. The Framework proposes six frames: (1) Authority is constructed and contextual; (2) Information creation is a process; (3) Information has value; (4) Research has its basis in inquiry; (5) Scholarship has value as conversation; and (6) Searching can be strategic exploration. These frames relate and contrast librarians as experts and students as novices.

Based on ACRL's Framework, Townsend et al. ${ }^{14}$ developed a Delphi study that engaged the opinions of expert practitioners on fifty potential threshold concepts. Ultimately, six concepts were chosen. In a recent study, these authors defined information literacy as "competence in working with systems of information to discover, evaluate, manage, and use information effectively in context, informed by an understanding of the social, political, cultural, and economic dimensions that affect the creation and dissemination of information within those systems." 15

Although the field of information literacy has been investigated extensively, most studies have presented a limited view of the issue by focusing on only one of the populations involved: librarians, students, or faculty and teaching staff. ${ }^{16}$ Studies that examined these three populations have emphasized their different roles and level of involvement ${ }^{17}$ and have found a connection between the nature of the relationship between librarians and teaching staff, the level of student satisfaction, and their later use of the library. ${ }^{18}$ Other studies have recommended that information literacy be integrated across the curriculum, ${ }^{19}$ as librarians can contribute their expertise in information retrieval and electronic information resources and instructors can provide discipline-related context for IL instruction. ${ }^{20}$

Therefore, the current study examines the perceptions and views of students, librarians, and faculty concerning four aspects of information literacy in academia: obstacles or difficulties confronted by students during their studies related to information 
literacy, student and faculty perceptions of the role of the library in these problems, their views about existing information literacy programs, and what an ideal program should look like. Special attention is given to the ways in which the relationship among these three groups impacts information literacy programs in academic settings. The term "relationship" refers to the nature of the cooperation and communication (or lack thereof) among library staff, faculty, and students, as well as the willingness of library staff and faculty to be attentive to students' needs and student learning. This study extends the literature on the subject by bringing together current views and opinions of the three populations involved to present a more comprehensive view of the challenges confronted by academia regarding teaching and student acquisition of information literacy skills. Using a qualitative methodology, the study provides a unique perspective into the perceptions of participants that was not always possible in prior quantitative studies.

\section{Research Environment}

The Department of the Arts has 190 students in three programs (bachelor's, master's, and doctoral) and 24 faculty staff. The Aranne Central Library at Ben-Gurion University provides information services for all faculties except medical sciences. Information literacy instruction consists of three different programs:

1. Introduction to library services: an online tutorial that introduces B.A. students to the main library services and resources. This is compulsory for all students.

2. Group tutorials: In-class teaching sessions developed in cooperation with faculty members that focus on searching strategies and information resources in a specific area related to a course.

3. Personal consultations: Personal and customized instruction that is available to students and faculty members by appointment with a librarian expert in their field.

\section{Literature Review}

\section{Students as Information Users}

The majority of students today belong to the "millennial" generation, or "Gen Y." ${ }^{21}$ They are the first generation exposed to the computers and to the Internet from a very young age. These digital natives have been able to adopt and use technology in all aspects of their lives (family, work, and leisure) in a way unknown to previous generations. Millennials have a consumer-oriented attitude, so they perceive higher education as a service characterized by accessibility, availability, and variety. ${ }^{22}$ They were born into a reality defined by immediate access to vast amounts of information that requires almost no effort on their part to be retrieved. Therefore, they are generally unwilling to invest significant time and effort to retrieve needed information. ${ }^{23}$

Previous research has shown that the information-seeking behavior of millennials is problematic: regardless of their success in retrieving relevant information, students felt confident in their searching abilities. Studies showed that they would rather search for information on the Internet, using Google-like search strategies to which they have grown accustomed from childhood, making it difficult for them to search and retrieve information efficiently from more complex academic databases ${ }^{24}$ and to effectively evaluate the content retrieved..$^{25}$

Alongside these changes in students, academic requirements have also evolved. If, in the past, students depended solely on information provided by the library, today they are expected to navigate through enormous amounts of information-a confusing and often overwhelming task. ${ }^{26}$ Many find it difficult to meet the expectation that they will find and retrieve relevant information in this complex information environment. ${ }^{27}$ 
Yet the majority of students still view the library as a place for book storage and not as an organization providing information services that can assist them in their research, and they consider information literacy programs to be less important than do faculty and librarians. ${ }^{28}$

\section{Faculty Perceptions}

Past studies have examined the different ways in which faculty members conceptualize students' information and research skills that will result in their "becoming confident and autonomous learners and thinkers." ${ }^{29}$ Faulty members perceive these skills as a basic set of scaffolds, related to general education, that help students find the information they need and acquire different modalities of information management, which range from retrieval skills to critical thinking and analysis. These skills are developed through a deep engagement in specific tasks related to disciplinary practices: 1) creating and analyzing empirical evidence; 2) developing an awareness of disciplinary contexts; and 3) interpreting information and creating texts. ${ }^{30}$

Faculty views about information literacy skills are essential to developing effective IL programs because they have regular, direct contact with the students and know the academic requirements in their fields. Studies have shown that teaching staff recognize the centrality of these skills in academic work and the need to improve them, but they put less emphasis on searching capabilities. ${ }^{31}$ The importance given by the academic institution to information literacy was revealed by Kuh and Gonyea, ${ }^{32}$ who reported that institutions that set higher standards for academic work compel students to effectively use the library that was shown to make students work harder to meet their teachers' expectations. Using the library results in their developing information literacy skills such as information evaluation and integration and thus applying these skills in other areas of life. Academic institutions have developed and integrated new perspectives on information literacy. The AAC\&U Value rubric is one of these new perspectives based on learning outcomes. This outline encompasses different aspects of students' learning such as intellectual and practical skills (that is, inquiry and analysis, critical and creative thinking), personal and social responsibility (in other words, civic engagement and ethical reasoning) and integrative learning. ${ }^{33}$

Saunders claimed that a large number of faculty did not understand the meaning of the term information literacy, had no plan as to how to incorporate these skills into their courses, nor a concrete idea on who should be responsible for imparting this knowledge. ${ }^{34}$ According to Watson, most faculty did not believe there was a need for a stand-alone IL course, and deciding how much time to allocate to the subject in their courses depended on how much time they could spare. Although they had a positive view of the library's literacy programs, they viewed librarians as service providers and not as their peers; they were unsure of their teaching abilities. ${ }^{35}$

\section{The Librarian's Role}

Taking responsibility for developing and instructing IL programs was a natural transition for librarians who have provided such instruction and guidance to users since the advent of electronic databases and public access Internet. However, librarians have had mixed feelings regarding their teaching role because most have received little or no formal pedagogical training, developing their teaching skills on the job. ${ }^{36}$

Bronstein interviewed reference librarians who reported that, in the past, teaching was limited to bibliographic instruction. Although there is now a need for more comprehensive information literacy programs that expose students to the wide variety of sources available in the library's collection, as well as up-to-date information-seeking strategies, current programs are short and focus only on using specific sources because 
students are usually impatient and uninterested. ${ }^{37}$ Nalani Meulemans and Carr examined changes in librarians' perceptions about their role in developing a collaborative relationship with faculty. They asserted that, although the relationship with faculty is currently asymmetric and most of the power resides with the faculty who have direct access to students, it is important to develop a genuine dialogue that will serve their mutual interests, as well as those of the students. ${ }^{38}$

\section{Information Literacy Programs}

Academic libraries designed and implemented a wide variety of information literacy programs in the last two decades as part of their effort to maintain the library as an integral part of academic life. Some of these programs were developed in nontraditional settings such as trivia contests and computer gaming that sought to engage students and lower their anxiety level. ${ }^{39}$ Mayer and Bowles-Terry reported on a recently developed program, "Managing and Navigating the World of Information," that covered information-related areas such as retrieval, evaluation, accessibility, and research basics. ${ }^{40}$

Henderson et al. found that, after taking part in one of these integrative workshops, students' self-confidence, as well as their searching capabilities, showed clear improvement. ${ }^{41}$ Other studies described different projects that integrated information literacy programs into academic curricula, reporting on students' success using these skills in their courses ${ }^{42}$ and stating that cooperation between librarians and faculty is essential in developing successful information literacy programs. ${ }^{43}$ Hofer, Townsend, and Brunetti proposed a different approach: develop IL programs based on understanding the obstacles faced by students when interacting with information. ${ }^{44}$

\section{Methodology}

The study examined four research questions related to the three populations interviewed and the interactions between them:

1. What obstacles related to information literacy are confronted by students, faculty, and librarians, in the opinion of each group?

2. What do students and faculty think about acquiring information literacy skills?

3. What is the relationship among students, faculty, and librarians? In what ways does this relationship impact the way information literacy is taught?

4. What would be the ideal information literacy program, according to each group?

The qualitative paradigm was chosen as the method for this study because interpretative processes allow the researcher to understand the meaning that individuals and/or groups ascribe to a social or human problem. Qualitative methods allow a complex issue or phenomenon to be explored in its natural context or setting, identifying variables that cannot be easily measured and achieving a detailed understanding of the issue. This level of detail can be established only by talking directly with people in their homes or places of work, allowing them to tell their stories. Also, this method gives researchers more freedom from the influence of findings in the literature. Qualitative research empowers individuals to share their stories, make their voices heard, and minimize the disparity of power that often exists between a researcher and participants in a study. ${ }^{45}$

The purpose of this study was to examine the interactions among the three groups of participants - students, faculty from the art department, and library staff. Purposive sampling was used to recruit participants based on the researchers' judgements. ${ }^{46}$ Thirty-two people were interviewed for the study: 15 students, 10 faculty members, and 7 librarians. Students were art history majors and were recruited until data saturation was reached. Faculty members and librarians were purposely selected, and the sample included members of the Department of the Arts at Ben-Gurion University (Beersheba, Israel) and the library staff at the university library. Participants from 
the three populations examined were recruited through the Zalman Aranne Central Library. Faculty, students, and librarians participated in the study voluntarily. The age range of participants was as follows: students 22-29, faculty 29-56, and librarians 27-67 years of age. All participants, as well as both researchers, are Hebrew speakers; the interviews were conducted in Hebrew. The transcripts of the interviews were later translated into English after the completion of the data analysis.

Semistructured interviews were chosen as the method of data collection because they "allow the investigator to probe, to clarify, and to create new questions based on what has been already heard." ${ }^{47}$ Interviews are personal interactions in which a connection is made between the interviewer and the respondent that piece together different elements of a story, reaching a common meaning of the issues. The use of semistructured interviews allowed researchers to reach a deeper understanding of the participants' views and perceptions of the issues under study.

Interviews lasting between 45 and 90 minutes were carried out at Ben-Gurion University between October 2013 and May 2014. All interviews were recorded, transcribed, and proofread. A different set of questions was used for each population (see appendix A). The survey used to interview students focused on their experiences when writing a paper, looking for information for their studies, the difficulties they encountered, and their interactions with the campus library. The surveys assigned to the faculty and the librarians asked participants to share their perceptions about the challenges students face when acquiring information literacy skills and the roles of both the department and the library in helping students overcome these challenges.

\section{Data Analysis}

Data collected during the interviews were analyzed using a thematic analysis approach, which involved encoding qualitative information. More specifically, thematic analysis facilitates identifying, analyzing, and reporting patterns or themes within data. A theme is a possible pattern found in the information that describes and organizes the observations. ${ }^{48}$ Thematic analysis can be essentialist or realistic in its method, which reports experiences, meanings, and the reality of participants. This provides a more comprehensive and nuanced account of particular themes, or a group of themes, within the data. ${ }^{49}$

Once data from the interviews were fully transcribed, they were read several times, and preliminary notes were taken until it was possible to classify all the data from the interviews into categories by comparing pieces of data with similar or related content. The classification process continued until all content was categorized and groups of related categories were arranged by themes. These themes rearranged the data in relation to the research question and represented some level of patterned response or meaning within the data set. ${ }^{50}$ The process continued until saturation was reached.

\section{Findings}

The following section presents the categories resulting from thematic analysis of the data. The analysis reflects different aspects involving information literacy skills in academia: the students' perceptions about the difficulties they encounter when interacting with information; the faculty's perceptions of these difficulties; the effect that the relationship between faculty and librarians has on information literacy training on campus; and a conceptualization of what an ideal information literacy training should look like, according to participants' perceptions.

\section{Students' Learning Difficulties Related to Information Literacy}

The first research question examined the difficulties or obstacles that students encountered when trying to acquire information literacy skills. Students talked about 
numerous problems in their interviews. For example, the difficulty in looking for information for a research study:

I had a hard time finding the right search term. That is, to understand what I'm looking for. The problem is that you need the things, you need to start somewhere, and here's the problem, where to start searching. This is my major difficulty. How to get into the subject and start searching.

Their inability to use the library's resources:

I feel ashamed to ask for help at the reference desk because I'm a senior and I ask the librarian stupid questions. I feel very awkward. Although she helps me, it feels not ok to ask questions I should know the answers to. Total ignorance.

The apparent gap between the level of their information literacy skills and the expectations of the faculty:

The teacher didn't even ask us if we know how to search before giving the assignment. They believe we know everything because we took the introductory tutorial and we should have learned the material in the tutorial. They teach a little bit here and there and they think we know how to search enough to write a paper, that we can do everything alone.

Teaching techniques that interfere with obtaining information literacy skills:

We rely on things they [the faculty] upload. That's what they do so we don't need to search for information on a specific project. When they asked for additional sources, I search the Internet, a trial and error thing, until you learn how to search properly.

Students' impatience and reluctance to invest time and effort to search for information:

Searching for information takes time. I think that part of the problem is that I don't have the patience to do a proper search because I'm used to everything being immediate and fast.

The challenges faced today by the students who participated in the study related to information literacy were among the most significant issues revealed during the interviews. Echoing earlier research, findings from this study indicated that students had difficulty understanding how and where to start a search. The hindrance was a lack of knowledge about the information sources accessible to them..$^{51}$ These studies posit that the wide variety of sources available to the students has become an obstacle that makes it harder for them to find their way among the confusing information environment, especially when they are lacking necessary skills. It seems this obstacle is not unique to Israeli students; the ACRL Framework recognizes how important it is for students to be knowledgeable about the information sources available to them when it states that "developing familiarity with the sources of evidence, methods and modes of discourse in the field assist novice learners to enter the conversation." ${ }^{52}$ Being used to searching on easy and quick information interfaces that require almost no effort on their part, students revealed they were either not willing or patient enough to invest time and effort searching for information on the library's databases.

This finding supports studies on millennials, a generation used to a wealth of information but lacking advanced searching skills, who found it difficult to search the 
library's databases because they were used to the ease and friendliness of Internet searching. ${ }^{53}$ In their study about troublesome concepts in information literacy, Hofer, Townsend, and Brunetti describe how students made explicit comparisons between libraries and Google that reflect their clear preference for the efficiency and userfriendliness of the search engine and their perception of the library resources as arcane. ${ }^{54}$

Regardless of the difficulties they encountered, students who participated in the study were aware of the importance of acquiring information literacy skills and getting to know the information resources available to them; they acknowledged their responsibility to develop their information skills. This finding does not support Kim and Shumaker's study, in which students did not value information literacy training, reported not having received sufficient training, and having to rely on fellow students and self-learning for help. ${ }^{55}$ Students also reported staying away from the library and librarians because they perceived them as threatening and confusing. These perceptions echo findings from other studies involving library anxiety in which students did not seek help from the library due to negative experiences and stereotypical thinking. ${ }^{56}$ Hofer, Townsend, and Brunetti asserted that identifying and understanding the places and situations that incite negative emotions of students "can pinpoint where to look for the underlying thresholds that students need to cross in order to get un-stuck." 57

\section{Faculty Perceptions of the Students' Difficulties}

Faculty members believe that taking the tutorial too early in their studies is one of the main reasons for the difficulties encountered by students:

They have a really hard time at first, they hesitate and get stuck. They feel overwhelmed with a million things that distract them and feel unsure about their abilities, they don't have the ability to search yet.

They believe that students received information literacy training in other courses:

I'm shocked. I tell them: You probably got the training at your other department and they say no. This is surprising and I cannot believe this is so. It looks strange to me that there is no training. That is, I know there is a basic tutorial. They know how to search the catalog. I know that some of the teachers do it in class and others do nothing at all.

Other faculty members blame their own lack of knowledge as the reason for their students' difficulties:

With all of our talk about progress, we make the same mistakes as past generations: that is, to fear new things, not to teach it for fear that you don't really understand or know it. We let the younger generations discover it for us, but not in a responsible and smart way.

They also believe that easy and almost unlimited access to information can become an obstacle for students:

One of the issues is the accessibility of information. It is very easy to get information and that's great, but this can also lead to superficiality. That is, it is hard for them to find information on more complex questions. Google cannot answer complex questions. Wikipedia cannot answer complex questions. To differentiate between them is not always easy.

Some faculty members take some of the responsibility for the difficulties students faced: 
At the end of the day it [information literacy training] gets pushed aside because we have so much material to teach, so much work to do with them that it comes up only occasionally in class. We as teachers have to remind ourselves about the importance of information, to make it a part of the conversation.

Faculty perceptions about information literacy, as revealed in the interviews, are positive: they understand the significance of information skills and appreciate the obstacles students face about the subject. In the interviews, they talked about exposing students to information databases, electronic and printed sources, as well as developing their searching skills and critical thinking. These findings do not support Dubicki, who claimed that faculty members believe information skills are important primarily for learning skills, and less so regarding searching skills. ${ }^{58}$ Faculty described a complex information environment that came as a result of developments in information technology and demanded higher levels of skills to function effectively in it. ${ }^{59}$

The interviews with the librarians revealed that they are aware of the obstacles students face when interacting with information. They explained that because of the students' high level of technology skills, they come to the reference desk to ask for help with questions dealing with complex subjects and not technique. ${ }^{60}$

\section{The Perception of the Academic Library and its Role}

The second research question looked at students' and faculty's perception of the library and its role. Although the library was mentioned by several students as one of the tools available to them to access information, they also expressed fear about using the library and confusion about the organization of its collections. As a result, many students avoided visiting:

I was so afraid I didn't even go inside, I didn't know how to deal with it, how to confront that place. I know that we need to search for information but I still don't understand how. So when I was a freshman I was never there until I had to write a paper and practically moved in here. You learn what you need when you don't have a choice.

Students talked about their preference for electronic information over visits to the library:

I'm really happy that we have databases, they give me peace. I would rather search for information on a database than come to the library. Libraries have always frightened me. And books are too big, too long. For a long time, I didn't even know how to find a book, I don't understand how information is organized and I was in shock for two years.

Students often lack basic knowledge about how a library works:

I have no idea what reference is. So, there are librarians that you can ask for help? I didn't know. I always approached someone older for help, but I didn't know if he was a librarian. Do librarians wear tags?

Many faculty members interviewed talked about the central role the library plays in teaching and research:

The library provides us with oxygen. Without the library we have no oxygen to breath[e]. We are very limited. It is easy to see the difference between a student that studies at the library and finds information from databases and a student that learns only from us. Even 
if we are great teachers and we love to give and teach, and we know how to do it, there is no comparison between a student that uses the library and one that doesn't.

The second issue raised by the faculty was their perception of the library's role. Findings from the interviews show that faculty members believed the library has a central role in the learning process, especially at the outset when students have yet to acquire the ability to evaluate information sources. Visiting the library and getting to know its resources is essential in their eyes, and they try to teach by example by visiting the library frequently. This finding contradicts studies by Julien and Pecoskie, as well as Watson, claiming that the connection with the faculty is getting lost; they hardly visit the library, and they are not acquainted with or value its services. ${ }^{61}$ We suggest that this discrepancy can be a result of the types of materials collected by the Art History library (examples: art books, prints), which are yet to be fully digitized, so the print format remains the main form of access.

Librarians are aware of the negative image the library has among students and are eager to change it through better, nonjudgmental service that displays empathy and patience. The study dones by Henry et al. presents an example of librarians trying to connect with students by making short videos in which they talk about themselves, their hobbies, and their areas of expertise and providing various ways to contact them. ${ }^{62}$

\section{Relationship between Faculty and Librarians and its Impact on Teaching IL Skills}

The third question considered the relationship among students, faculty, and librarians and the impact that this relationship has on the way information literacy is taught. The first element of this relationship is the cooperation among the parties. Faculty perceives the cooperation with library staff as positive and reported a number of successful cooperative information literacy programs:

When planning an information literacy project, we would always want the librarians' input. We would also want someone from research, that is, someone from the academic staff to lead the program, who will give that point of view. We have been cooperating with the library staff for many years; our relationship with them is very important.

However, on some occasions, cooperation has not been successful:

There was a problem with the interaction with the librarian formerly in charge, who was very nice but not very effective. Or she did not know what to do; I could never understand what was limiting her. So it [the program] never really came through.

Librarians perceived cooperation with faculty as important but sometimes painful work that takes a lot of effort, occupies large part of their time, and is constantly developing. They noted both positive and negative communications with faculty. Academic departments cooperate with the library regarding information literacy training and collection development in a relationship that was built over years:

I had a very close relationship with the department, including the secretary. We were partners. I sent them lists of new books, all kind[s] of updates like new databases. They knew me and turned to me for help. This is how it should be with all departments. We both serve the students so we need to work together.

Librarians believe it is their job to initiate and maintain the relationship with faculty, not only in relation to training but also to convince faculty about the importance of having it: 
Librarians need to contact whoever is teaching freshmen in the departments helshe is in charge of. To phone, and talk with the head of department, to faculty about the training we offer [at the library], that we are here and we are always available to help in all areas-not only about the tutorials. Of course, the faculty has to want it, they have to take it up and develop it.

One of the issues in librarians' relationships with faculty was that they were not treated as equals:

They don't see us as colleagues, that's the problem. There was one attempt to integrate the training into courses in the department that met with a lot of resistance from the faculty. Although it is done all around the world, they were... not ready for it here. Or maybe they don't believe it is that important.

Another participant believed that mistrust of the library is based on the lack of knowledge about what the library has to offer:

There are some faculty members who could use an introduction about the library, especially the new ones. Some of them are aware of it and they come to us for a basic tutorial about library services. But they are mostly younger ones, but the more senior one you cannot change, they think they know everything and they are not even interested.

Still, librarians see it as a personal challenge to build a relationship with the faculty:

I see it as a personal failure ... maybe not failure, but something that I didn't succeed at. But slowly I have been able to form a relationship with some of them [faculty], they know I'm here, turn to me for help, trust me. So the next step is to convince them to give me another chance, to let me show them how I work and that my work is important.

Content analysis of the interviews revealed that faculty members view cooperation with librarians as positive and important; a good relationship and open communication are keys to helping students succeed in their studies. They were willing to further the cooperation with librarians in developing information literacy programs, as well as continue research regarding the librarian's point of view and knowledge as central in developing information literacy instruction. These findings support Nalani Meulemans and Carr's four essential characteristics of successful cooperation: a common and clear goal, mutual respect, tolerance, and trust. ${ }^{63}$

Prior research has shown that, although librarians were the ones initiating the contact with the faculty as part of the library's marketing efforts, getting faculty involved in developing a variety of information literacy projects (such as class tutorials and personal training sessions) were positive examples of their partnership in information literacy training. ${ }^{64}$ However, despite these efforts, librarians in this study discussed the sometimes difficult relationship with faculty. They described instances in which faculty members did not see them as colleagues and did not trust them to teach a class in their department. Similarly, Julien and Barker ${ }^{65}$ found that faculty viewed librarians as service providers and not colleagues with equal teaching abilities. Nalani Meulemans and Carr also pointed to a negative attitude by faculty toward librarians based on a lack of knowledge about the library's services and the librarians' capabilities. ${ }^{66}$ These findings reinforce the need for cooperation and open dialogue between them.

Findings show that the relationship among the three groups is hierarchical. Although the roles of faculty and librarians are different, both populations were perceived by 
students as authority figures. Librarians perceive themselves as intermediaries between students and faculty, wishing that their knowledge and experience were acknowledged and that they were not perceived only as service providers. This finding echoes a reference by Townsend et al. to librarians as experts, who have substantial knowledge in the field of information science ${ }^{67}$ Similar findings were reported in earlier studies that considered the views of students, faculty, and librarians. ${ }^{68}$

As a result of the existing hierarchy, collaboration with students was not mentioned in the interviews. Both librarians and faculty were not fully aware of the various difficulties students face, and neither group provided clear answers, despite the fact that the students suggested a number of solutions. Allison and Ismail also stressed the importance of allowing students to voice their opinions and have opportunities to contribute and attempt to develop tools and services for their own use. If these steps are not taken, efforts made by faculty and librarians may turn out to be ineffective. ${ }^{69}$

\section{Information Literacy Training}

As a result of the difficulties encountered by the students when learning, the three populations who participated in the study were asked to provide ideas and suggestions to make information literacy courses more effective and appealing. Students liked the idea of integrating information literacy training into a specific course and stressed the importance of hands-on practice:

It has to be a class with tasks. Because if you just sit in class and the teacher shows you how to search and what to search, it is pretty boring. Let me do it. Let me look for the information. For example, my task can be to search for information I need for other courses. The searches should be real, not fictive or theoretical.

Other students did not believe there was a need for a complete course that teaches information literacy, proposing a series of open lectures:

I don't see a reason to make a course out of it, because none of us are going to be librarians. If someone is interested, then yes, they should do it independently. But for the rest of us, one lesson is more than enough: how to search a database, how to use the electronic resources at the library, who to turn to for help at the library, or a meeting at the library... that could really be useful.

Students also talked about the timing of the course as important:

I think it should be studied during the second year of college. In our first year, there are mostly introductory courses, there are almost no papers to write that require serious information searching. In the second year we start writing papers. I think that is the best time to start. The first semester of the second year, and to have a refresher course at the beginning of the third year.

Faculty believed that training on the subject should be gradual and relevant to different stages of the degree:

At what time should they get the tools? I prefer they get them as soon as possible, right at the beginning of their studies. They will need the skills throughout the degree. When students get to my advanced class in their second year and they don't know how to use information sources, it is bad; it interferes with my class and my plans. 
Regarding who should give the tutorial, students had different ideas. Some of them prefer to receive the training from librarians:

I prefer somebody from the library. The teacher doesn't always have the energy and they won't explain it in depth like someone from the library would. They can also talk a little bit about the library services.

Some faculty members also prefer that librarians teach information literacy skills:

There are different opinions on the issue, whether a teacher or a librarian should teach the subject. I think that ideally, my job is twofold. To impart knowledge and to guide, methodology speaking. The use of research tools in the library, that is information sources, is a technical matter. Although I teach them in my course I would rather not do it because it is something technical and it doesn't require a faculty member. I do it because I don't have a choice.

The combination of faculty and librarian is the preferred choice both by students and faculty. A student says:

I would say both. That is, faculty are experts in their fields, but their goal is that we do it [search for information] by ourselves. So they have to teach us how to deconstruct a subject and put it back together. The librarian should teach how to do the actual search.

A faculty member described her ideal situation:

In my fantasy, it should be a course where a librarian teaches a couple of classes and they [the students] go to the library, and then someone from the department teaches some subject-related material. But, in principle, it should be a departmental course, designed by people who know and understand the problems and nuances of the field. We [faculty] don't always know all the new advances and updates that librarians know. The combination could be fantastic.

Librarians also believe that integrating information literacy training into departmental courses is the right way to teach these skills:

I think it is very, very important to integrate [information literacy training] with a course, and when we look at the contents of a course, there is always a lesson that deals with information sources where we can come in. The problem is that we take away from the time of the class. But every faculty member that has tried it, likes it. We have never had a complaint or did not ask us to come back the following year.

The last theme found during content analysis was the participants' view of an ideal information literacy tutorial. It was characterized by a number of features:

1. An independent class would integrate the tools and resources needed for art majors;

2. It would include practical training so students could apply the content of the course. (These first two items reflect those from other studies.) ${ }^{70}$

3. The course should give academic credit, but not be required.

4. The training should take place during the first semester of the second year. (Mayer and Bowles-Terry suggested that advanced information literacy training should be available for upper-level students challenged by more complex assignments. $)^{71}$ 
5. Cooperation between librarians and faculty is much needed. Each side should impart material in their field of expertise, because training tutorials developed by faculty and librarians collaborating were described as more successful than those done by faculty alone and prevents material from being repeated or absent from the training. ${ }^{72}$

Blackmore and Freeland proposed a different approach to developing an information literacy program based on threshold concepts that relates information skills to not only information searching but also emotions, cultural understandings, and bricolage. ${ }^{73}$

The study has a number of limitations. First, as to its focus: it examined a specific population of an academic department to determine their perceptions and understand their reality. Second, since this is a qualitative study, its sample is small and not representative of all students at Ben-Gurion University. Third, it does not intend to present an "action plan" to develop an information literacy program, but rather to analyze, comprehend, and give an interpretation to the textual data collected in the interviews.

\section{Conclusions}

I remember my days as a student, I try not to forget, and try to remember how difficult it was for me so I can understand the difficulties they [the students] face.

Information literacy should be understood as more than just applying routine procedures related to information skills. Information-literate individuals are able to recognize and understand their need for information, be knowledgeable about their information environments, know how to engage them, and use the information they find to resolve or fulfill their information needs. This study's contribution to the LIS field is twofold. First, it stresses that the interactions among three populations shape the process by which these skills are taught and acquired. Findings showed that obstacles faced by students, and the gaps encountered in the process, were the result of the nature of the relationship between the participants. The desire to change and improve existed in all three groups. Participants were aware of many of the problems that exist and wanted to find a solution. Therefore, open and continuous communication among the three populations was shown as essential in closing existing gaps and reducing some of the current difficulties. Training developed jointly by faculty and librarians, in which each part shares from their experience and knowledge, as well as taking into account the views and opinions of students, could provide students a more well-rounded education. Collaboration could also ensure having information literacy programs that work for everyone, which would be a more positive and fruitful academic experience for all stakeholders. Second, findings present a view on what the "ideal" information literacy program should look like based on the opinions of the three populations that participated in the study. Although this study focused on a specific academic department and a small group of librarians, we believe its findings have value since they might provide the tools and insights that will further the knowledge in the area of information literacy and readers will find them useful when designing an information literacy program. 


\section{APPENDIX A. Interview Questions}

\section{Students}

1. How do you perceive your ability to seek information?

2. How do you evaluate the search results?

3. Tell me about writing your first academic paper.

4. Tell me about your last experience writing an academic paper.

5. Do you feel confident in your searching skills before stating writing a paper?

6. What is the biggest difficulty you experience when writing a paper?

7. Do you think you received sufficient training and information from the art department on the subject of academic writing and searching for and evaluating information?

8. How have library training classes changed the way you look for information and your perception of the library?

9. What does the library represent in your eyes?

10. Please describe your feeling when using the library.

11. Do you think that the library has the tools to help you?

12. Do you think you are familiar with the library's services?

13. Can you tell me about a positive and a negative experience you had when using the library?

14. Can you try to describe how the ideal library training class should look?

\section{APPENDIX B. Interview Questions}

\section{Faculty}

1. Tell me about your position in the department.

2. How long have you been teaching?

3. What are the basic information literacy skills that any student should have today?

4. How do you evaluate the needs and knowledge that students' have regarding this subject?

5. What is the biggest difficulty students face when writing an academic paper?

6. Can you describe the department's policy on information literacy?

7. Tell me about the department's information literacy program.

8. How is it integrated into the department's courses and curriculum?

9. Who do you think should teach information literacy skills, the library or the department?

10. How would you describe the relations between the library and the department?

11. What do you think about the information literacy programs given today at the library?

12. What is missing? How can the library improve the training?

\section{APPENDIX C. Interview Questions}

\section{Librarians}

1. Tell me about your current role as a librarian.

2. Tell me about the information literacy programs at the library.

3. Which needs or obstacles do these programs address?

4. What is the purpose of the different programs?

5. Are these programs designed in advance, or tailored to the faculty's needs?

6. How do you evaluate these programs?

7. How do you identify the students' needs in this area?

8. How do you think students should be encouraged to visit and use the library? 
9. What is the significance of the relationship between the library and the department? What is the role of this relationship?

10. Whose job is it to initiate this relationship?

11. Who do you think should be in charge of designing and teaching information literacy?

12. What do you know about the department's information literacy programs?

13. Does the department encourage the use of the library? If yes, in what way?

14. Does the library encourage the department's involvement in the design and implementation of information literacy programs? If so, in what way?

\section{Notes}

1. J. O'Gorman and B. Trott, "What Will Become of Reference in Academic and Public Libraries?" Journal of Library Administration 49, no. 4 (2009): 327-39.

2. P.G. Zurkowski, "The Information Service Environment: Relationships and Priorities," Related Paper No. 5 (1974), available online at http://files.eric.ed.gov/fulltext/ED100391.pdf [accessed 12 November 2015].

3. American Library Association, Presidential Committee on Information Literacy: Final Report (2008), available online at http://www.ala.org/acrl/publications/whitepapers/presidential [accessed 12 November 2015].

4. A. Lloyd, "Information Literacy Landscapes: An Emerging Picture," Journal of Documentation 62, no. 5 (2006): 570-83.

5. J. Bindé, "Towards Knowledge Societies: UNESCO World Report" (2005), available online at http://ictlogy.net/bibliography/reports/projects.php?idp=240 [accessed 15 December 2015].

6. H.B. Rader, "Building Faculty-Librarian Partnerships to Prepare Students for Information Fluency," College and Research Libraries News 65, no. 2 (2004): 74-77.

7. M. Deyrup and B. Bloom, "The Truth Is Out: How Students REALLY Search," Proceedings of the Charleston Conference (2013), available online at http://docs.lib.purdue.edu/charleston/2012/ Users/2/ [accessed 2 December 2015]; O'Gorman and Trott, "What Will Become of Reference in Academic and Public Libraries?"; A. Taylor, "A Study of the Information Search Behaviour of the Millennial Generation," Information Research: An International Electronic Journal 17, no. 1 (2012), available online at http://InformationR.net/ir/17-1/paper508.html [accessed 15 November 2015].

8. P.S. Breivik, "21st Century Learning and Information Literacy," Change: The Magazine of Higher Learning 37, no. 2 (2005): 21-27.

9. A.D. Allison, The Patron-Driven Library: A Practical Guide for Managing Collections and Services in the Digital Age (New York, N.Y.: Elsevier, 2013); O'Gorman and Trott, "What Will Become of Reference in Academic and Public Libraries?"; Taylor, "A Study of the Information Search Behaviour of the Millennial Generation."

10. R. Bickley and S. Corrall, "Student Perceptions of Staff in the Information Commons: A Survey at the University of Sheffield," Reference Services Review 39, no. 2 (2011): 223-43; I. Datig, "What Is a Library? International College Students' Perceptions of Libraries," Journal of Academic Librarianship 40, no. 3 (2014): 350-56.

11. A. Lloyd, "Information Literacy the Meta-Competency of the Knowledge Economy? An Exploratory Paper," Journal of Librarianship and Information Science 35, no. 2 (2003): 87-92.

12. Thomas P. Mackey and Trudi E. Jacobson, "Reframing Information Literacy as a Metaliteracy," College \& Research Libraries 72, no. 1 (2011): 62-78, available online at https://doi.org/10.5860/ crl-76r1 [accessed 21 March 2018].

13. ACRL, Framework for Information Literacy for Higher Education (2016), available online at http://www.ala.org/acrl/sites/ala.org.acrl/files/content/issues/infolit/Framework_ILHE.pdf [accessed 10 December 2016].

14. L. Townsend, A.R. Hofer, S.L. Hanick, and K. Brunetti, "Identifying Threshold Concepts for Information Literacy: A Delphi Study," Communications in Information Literacy 10, no. 1 (2016): 23-49.

15. Ibid., 33.

16. For studies examining students: N. Aharony and J. Bronstein, "Academic Librarians' Perceptions on Information Literacy: The Israeli Perspective," portal: Libraries and the Academy 14, no. 1 (2014): 103-19; J. Bronstein, "The Role and Work Perceptions of Academic Reference Librarians: A Qualitative Inquiry," portal: Libraries and the Academy 11, no. 3 (2011): 791-811; L. Ismail, "What Net Generation Students Really Want: Determining Library Help-Seeking Preferences of Undergraduates," Reference Services Review 38, no. 1 (2010): 10-27; S.J. Bell and J. Shank, 
"The Blended Librarian: A Blueprint for Redefining the Teaching and Learning Role of Academic Librarians," College E Research Libraries News 65, no. 7 (2004): 372-75. For studies considering librarians' perceptions and opinions: R. Bickley and S. Corrall, "Student Perceptions of Staff in the Information Commons: A Survey at the University of Sheffield," Reference Services Review 39, no. 2 (2011): 223-243; I. Datig, "What Is a Library? International College Students' Perceptions of Libraries," The Journal of Academic Librarianship 40, no. 3 (2014): 350-356; R. Greenberg and J. BarIlan, "Information Needs of Students in Israel: A Case Study of a Multicultural Society," Journal of Academic Librarianship 40, no. 2 (2014): 185-91. For studies examining faculty and teaching staff: E. Dubicki, "Faculty Perceptions of Students' Information Literacy Skills Competencies," Journal of Information Literacy 7, no. 2 (2013): 97-125; Y. Nalani Meulemans and A. Carr, "Not at Your Service: Building Genuine Faculty-Librarian Partnerships," Reference Services Review 41, no. 1 (2013): 80-90; E.M. Watson, "Taking the Mountain to Mohammed: The Effect of Librarian Visits to Faculty Members on Their Use of the Library," New Review of Academic Librarianship 16, no. 2 (2010): 145-59.

17. S.U. Kim and D. Shumaker, "Student, Librarian, and Instructor Perceptions of Information Literacy Instruction and Skills in a First Year Experience Program: A Case Study," Journal of Academic Librarianship 41, no. 4 (2015): 449-56.

18. N. Aharony, "Information Literacy in the Professional Literature: An Exploratory Analysis," Aslib Proceedings 62, no. 3 (2010): 261-82; I. Koneru, "Strategic and Collaborative Approaches for Fostering Information Literacy via an Information Portal," DESIDOC Journal of Library E Information Technology 26, no. 6 (2006): 3-12; E. Lindsay and E. Blakesley, "Distance Teaching: Comparing Two Online Information Literacy Courses," Journal of Academic Librarianship 30, no. 6 (2004): 482-87.

19. B.J. D'Angelo and B.M. Maid, “Moving beyond Definitions: Implementing Information Literacy across the Curriculum," Journal of Academic Librarianship 30, no. 3 (2004): 212-17.

20. W.B. Badke, "Can't Get No Respect: Helping Faculty to Understand the Educational Power of Information Literacy," Reference Librarian 43, no. 89/90 (2005): 63-80; B. Fister, E.O. Hutchins, and K.H. MacPherson, "From BI to IL: The Paths of Two Liberal Arts Colleges," in Crossing the Divide: Proceedings of the Tenth National Conference of the ACRL (Mar. 15-18, 2001), Denver, Colo. (Chicago, Ill.: ACRL, 2001): 203-12; M. Oakleaf, M.S. Millet, and L. Kraus, "All Together Now: Getting Faculty, Administrators, and Staff Engaged in Information Literacy Assessment," portal: Libraries and the Academy 11, no. 3 (2011): 831-52.

21. Allison, The Patron-Driven Library; C.H. Becker, "Student Values and Research: Are Millennials Really Changing the Future of Reference and Research?" Journal of Library Administration 49, no. 4 (2009): 341-64; Taylor, "A Study of the Information Search Behaviour of the Millennial Generation."

22. Allison, The Patron-Driven Library.

23. M. D'Couto and S.H. Rosenhan, "How Students Research: Implications for the Library and Faculty," Journal of Library Administration 55, no. 7 (2015): 562-76; Taylor, "A Study of the Information Search Behaviour of the Millennial Generation."

24. Greenberg and Bar-Ilan, "Information Needs of Students in Israel."

25. Bronstein, "The Role and Work Perceptions of Academic Reference Librarians"; Deyrup and Bloom, "The Truth Is Out."

26. D'Couto and Rosenhan, "How Students Research."

27. Deyrup and Bloom, "The Truth Is Out"; O'Gorman and Trott, "What Will Become of Reference in Academic and Public Libraries?"

28. L. O'Connor and K. Lundstrom, "The Impact of Social Marketing Strategies on the Information Seeking Behaviors of College Students," Reference E User Services Quarterly 50, no. 4 (2011): 351-65; Kim and Shumaker, "Student, Librarian, and Instructor Perceptions of Information Literacy Instruction."

29. S. Boon, B. Johnston, and S. Webber, "A Phenomenographic Study of English Faculty's Conceptions of Information Literacy," Journal of Documentation 63, no. 2 (2007): 204-28.

30. Jonathan Cope and Jesús E. Sanabria, "Do We Speak the Same Language? A Study of Faculty Perceptions of Information Literacy," portal: Libraries and the Academy 14, no. 4 (2014): 475-501.

31. Dubicki, "Faculty Perceptions of Students' Information Literacy Skills Competencies."

32. G.D. Kuh and R.M. Gonyea, "The Role of the Academic Library in Promoting Student Engagement in Learning," College E Research Libraries 76, no. 3 (2015): 359-8

33. Association of American Colleges and Universities, Value Rubric Development Project, available online at https://www.aacu.org/value/rubrics [accessed 12 May 2017].

34. L. Saunders, "Faculty Perspectives on Information Literacy as a Student Learning Outcome," Journal of Academic Librarianship 38, no. 4 (2012): 226-36.

35. Watson, "Taking the Mountain to Mohammed."

36. H. Julien and S. Barker, "How High-School Students Find and Evaluate Scientific Informa- 
tion: A Basis for Information Literacy Skills Development," Library \& Information Science Research 31, no. 1 (2009): 12-17; Bell and Shank, "The Blended Librarian."

37. Bronstein, "The Role and Work Perceptions of Academic Reference Librarians."

38. Nalani Meulemans and Carr, "Not at Your Service."

39. M. Margino, "Revitalizing Traditional Information Literacy Instruction: Exploring Games in Academic Libraries," Public Services Quarterly 9, no. 4 (2013): 333-41; T.C. Porter, "Games and Activities: An Alternative Foundation for Library Instructional Learning," Codex: The Journal of the Louisiana Chapter of the ACRL 2, no. 2 (2012): 61-77.

40. J. Mayer and M. Bowles-Terry, "Engagement and Assessment in a Credit-Bearing Information Literacy Course," Reference Services Review 41, no. 1 (2013): 62-79.

41. F. Henderson, N. Nunez-Rodriguez, and W. Casari, "Enhancing Research Skills and Information Literacy in Community College Science Students," American Biology Teacher 73, no. 5 (2011): 270-7

42. A. Dinkelman, J.E. Aune, and G.R. Nonnecke, "Using an Interdisciplinary Approach to Teach Undergraduates Communication and Information Literacy Skills," Journal of Natural Resources \& Life Sciences Education 39, no. 1 (2010): 137-44; D. VanderPol and E.A.B. Swanson, "Rethinking Roles: Librarians and Faculty Collaborate to Develop Students' Information Literacy," Journal of Library Innovation 4, no. 2 (2013): 134-48.

43. Saunders, "Faculty Perspectives on Information Literacy"; D.C. Rollins, J. Hutchings, M.U.D. Goldsmith, and A.J. Fonseca, "Are We There Yet? The Difficult Road to Re-Create Information Literacy," portal: Libraries and the Academy 9, no. 4 (2009): 453-73; M. Schwartz, "Are You Being Served?" Library Journal 140, no. 14 (2015): 38-40.

44. A.R. Hofer, L. Townsend, and K. Brunetti, "Troublesome Concepts and Information Literacy: Investigating Threshold Concepts for IL Instruction," portal: Libraries and the Academy 12, no. 4 (2012): 387-405.

45. J.W. Creswell, Qualitative Inquiry and Research Design: Choosing among Five Approaches (Thousand Oaks, Calif.: Sage Publications, 2012).

46. A. Shkedi, Words of Meaning: Qualitative Research-Theory and Practice (Tel-Aviv, Israel: Ramot, 2003, in Hebrew).

47. L. Westbrook, "Qualitative Research Methods: A Review of Major Stages, Data Analysis Techniques, and Quality Controls," Library \& Information Science Research 16, no. 3 (1994): 241-54.

48. R.E. Boyatzis, Transforming Qualitative Information: Thematic Analysis and Code Development (Thousand Oaks, Calif.: Sage Publications, 1998).

49. V. Braun and V. Clarke, "Using Thematic Analysis in Psychology," Qualitative Research in Psychology 3, no. 2 (2006): 77-101.

50. Ibid.

51. Greenberg and Bar-Ilan, "Information Needs of Students in Israel."

52. "ACRL Framework for Information Literacy for Higher Education,"

53. Deyrup and Bloom, "The Truth Is Out"; Taylor, "A Study of the Information Search Behaviour of the Millennial Generation"; Bronstein, "The Role and Work Perceptions of Academic Reference Librarians."

54. Hofer, Townsend, and Brunetti, "Troublesome Concepts and Information Literacy."

55. Kim and Shumaker, "Student, Librarian, and Instructor Perceptions of Information Literacy Instruction."

56. Bell and Shank, "The Blended Librarian"; Bickley and Corrall, "Student Perceptions of Staff in the Information Commons."

57. Hofer, Townsend, and Brunetti, “Troublesome Concepts and Information Literacy," 396.

58. Dubicki, "Faculty Perceptions of Students' Information Literacy Skills Competencies."

59. S. Virkus, "Information Literacy as an Important Competency for the 21st Century:

Conceptual Approaches," Journal of the Bangladesh Association of Young Researchers 1, no. 2 (2011):

15-29; S. Weiner, "Information Literacy and the Workforce: A Review," Education Libraries 34, no.

2 (2011): 7-14.

60. Bronstein, "The Role and Work Perceptions of Academic Reference Librarians."

61. Julien and Barker, "How High-School Students Find and Evaluate Scientific Information"; Watson, "Taking the Mountain to Mohammed."

62. C.L. Henry, K.K. Vardeman, and C.K. Syma, "Reaching Out: Connecting Students to Their Personal Librarian," Reference Services Review 40, no. 3 (2012): 396-407.

63. Nalani Meulemans and Carr, "Not at Your Service."

64. Dubicki, "Faculty Perceptions of Students' Information Literacy Skills Competencies"; I.R. Miller, "Turning the Tables: A Faculty-Centered Approach to Integrating Information Literacy," Reference Services Review 38, no. 4 (2010): 647-62; Saunders, "Faculty Perspectives on Information Literacy."

65. Julien and Barker, "How high-school students Find and Evaluate Scientific Information." 
66. Nalani Meulemans and Carr, "Not at Your Service."

67. Townsend, Hofer, Hanick, and Brunetti, "Identifying Threshold Concepts for Information Literacy."

68. Ibid.; Julien and Barker, "How high-school students Find and Evaluate Scientific Information: A Basis for Information Literacy Skills Development."

69. Allison, The Patron-Driven Library; Ismail, "What Net Generation Students Really Want."

70. Aharony and Bronstein, "Academic Librarians' Perceptions on Information Literacy"; Saunders, "Faculty Perspectives on Information Literacy as a Student Learning Outcome."

71. Mayer and M. Bowles-Terry, "Engagement and Assessment in a Credit-Bearing Information Literacy Course."

72. Nalani Meulemans and Carr, "Not at Your Service"; Kim and Shumaker, "Student, Librarian, and Instructor Perceptions of Information Literacy Instruction."

73. See the following two studies: M. Blackmore, "Student Engagement with Information: Applying a 'Threshold Concept' Approach to Information Literacy Development" (paper presented at the Third Biennial Threshold Concepts Symposium: Exploring Transformative Dimensions of Threshold Concepts, Sydney, July 1-2, 2010): 9-10; J. Blackmore, L. Hardcastle, E. Bamblett, and J. Owens, "Effective Use of Information and Communication Technology (ICT) to Enhance Learning for Disadvantaged School Students" (Deakin University, Australia, 2003), available online at tl.ie/ workgroupDocs/BlackmoreFreeland.pdf [accessed 13 December 2016]. 